\title{
Did Somebody Say Neoliberalism?: On the Uses and Limi- tations of a Critical Concept in Media and Communication Studies
}

\author{
Christian Garland* and Stephen Harper**
}

\author{
* University of Warwick, UK and Fellow of Fellow of the Institut für Kritische Theorie, Freie \\ Universität Berlin \\ christiangarland@hotmail.com \\ ** University of Portsmouth, School of Creative Arts, Film and Media, Portsmouth, UK, \\ stephen.harper@port.ac.uk
}

\begin{abstract}
This paper explores the political-economic basis and ideological effects of talk about neoliberalism with respect to media and communication studies. In response to the supposed ascendancy of the neoliberal order since the 1980s, many media and communication scholars have redirected their critical attentions from capitalism to neoliberalism. This paper tries to clarify the significance of the relatively new emphasis on neoliberalism in the discourse of media and communication studies, with particular reference to the 2011 phone hacking scandal at The News of the World. Questioning whether the discursive substitution of 'neoliberalism' for 'capitalism' offers any advances in critical purchase or explanatory power to critics of capitalist society and its media, the paper proposes that critics substitute a Marxist class analysis in place of the neoliberalism-versus-democracy framework that currently dominates in the field.
\end{abstract}

Keywords: Neoliberalism, Marxism, Critical Theory, Critical Media and Communication Studies, Hackgate

The media and communication studies textbooks of the early 1980s constituted an ideological battleground for the struggle between liberal pluralism, on the one hand, and Marxism, on the other (see, for example, Gurevitch et al. 1982). Under the influence of European critical theory and British cultural studies, Marxist communication scholars talked of capitalism and class struggle, and accused pluralists of underestimating structures of domination (Hall 1982). With stronger roots in US sociological tradition, pluralist media critics advocated for democracy, chastising Marxists for their economic determinism or functionalism. While it is certainly possible to read the history of the relationship between Marxist and liberal pluralist approaches to media and cultural studies in terms of a series of rapprochements and overlaps (McLennan 1989), there can be little doubt that in recent decades, the pluralist perspective has all but vanquished its erstwhile ideological competitor.

Marxism has always, of course, been marginalised in media and communication studies. In the twentieth century, for example, McCarthyism in the US and the Radikalenerlass in Germany restricted the activities of Marxist communication scholars. Nevertheless, in the 1960s and 1970s, Marxism was a driving force in workers' struggles and a tangible presence in the academy. The critical marginalisation of Marxism became particularly apparent with the ebbing of class struggle in the 1980s and 1990s. In these decades, the disciplines of media and cultural studies, under the sway of a celebratory postmodernism, came to distinguish their pluralist wisdom from the supposedly "elitist" positions of the different Marxist traditions, continually emphasising the eclectic nature of their own standpoints and of the media cultures they critiqued. According to the pluralist paradigm, the newspaper reader, the television viewer, the radio listener are free to consumer culture as active, empowered, resistant audiences in a marketplace of ideas underpinned and sustained by liberal democratic ideology. Following on from this there is the recognition that capitalism may have some shortcomings, but it is 'the best we've got' and so must be made the best of: the capitalist system and its media institutions are seen to represent the best possible arrangement of things. The popularity of this perspective in the cultural studies milieu of the 1990s has reconfigured the ideological co-ordinates of cultural and media theory, so that for many critics today, the task of media and cultural criticism is no longer to critique capitalism, but to defend the principles of "democracy" and "pluralism" against unwelcome encroachments of the market - 
encroachments often understood as so many manifestations of "neoliberalism" or the "neoliberal agenda".

Indeed, the hegemony of pluralism in media and cultural studies has been accompanied by some telling terminological shifts. The word "capitalism", for instance, has all but vanished from the lexicon of the left - as sure a sign as any, as Slavoj Žižek $(2007,212)$ notes, of capitalism's ideological triumph. In the 1990s, as Boltanski and Chiapello (2005, ix) observe, "the term [capitalism] was simply struck from the vocabulary of politicians, trade unionists, writers and journalists - not to mention social scientists, who had consigned it to historical oblivion". Today, we would suggest, the term "neoliberalism" has largely replaced "capitalism" (and its more optimistic variant "late capitalism") in media and cultural studies discourse and the former word now appears in contexts where once we would have expected to have read the latter. In an article on media ideologies, to take just one example, the prolific discourse analyst Teun van Dijk $(2006,121)$ discusses how media audiences recognise "racist, sexist or neoliberal" arguments. As such formulations suggest, the Marxism/pluralism dyad of yesteryear has largely given way to a new paradigm structured by the binary opposition between neoliberalism, on the one hand, and democracy (or, sometimes, in the Laclauian formulation, "radical democracy"), on the other. Today, it is neoliberalism, rather than capitalism as such, that preoccupies many academics working in the fields of media and cultural studies. As one leading media scholar, Natalie Fenton $(2009,56)$, puts it, "if media studies must do anything, then it must analyze and explain the cultural and political significance of [the] neoliberal market doctrine".

In itself, this enterprise is not necessarily misguided. In fact, as we argue below, much valuable work in media and cultural studies has proceeded on this basis. Yet even among critics who have embraced the term, neoliberalism is sometimes hazily defined and its conceptual intelligibility is often taken for granted (Mudge 2008). This paper tries to clarify the relevance and utility of the concept of neoliberalism for critical scholarship in media and cultural studies, questioning whether the hegemonic acceptance of the term offers any genuine increase in critical purchase or explanatory power to critics of capitalist society and its media. In particular, it is argued that it has become something of an accepted practice in media and cultural studies to identify "neoliberalism" rather than capitalism per se - as the ultimate target of critique. In Fenton's terms, neoliberalism is a "market doctrine" which has supplanted an earlier version of the same market in which the liberal democratic state imposed "checks and balances" on capitalist power and critiques of neoliberalism are often animated by a reformist concern to return to the former, social democratic vision by "reclaim[ing] the state" (Wainwright 2003) from the forces of the market. The danger of such critiques, we argue, is that they may lead to a tepidly agonised hankering after a long-gone "fairer", "more democratic" capitalism and a call for the "renewal" of Keynesianism. In relation to the media and cultural industries, meanwhile, the attack on neoliberalism, while commendable in itself, all too often entails a problematic defence of "public service" broadcasting as a bulwark against commercialisation.

This paper seeks to contribute to a more radical critique of the functioning of neoliberalism within critical discourse, challenging the assumptions frequently underlying the use of the term and its application to the media and cultural industries. Our own perspective on questions of media power is informed by Marx and Engels' well-known contention in The German Ideology that

the ideas of the ruling class are in every epoch the ruling ideas, i.e. the class which is the ruling material force of society, is at the same time its ruling intellectual force. The class which has the means of material production at its disposal has control at the same time over the means of mental production, so that thereby, generally speaking, the ideas of those who lack the means of mental production are subject to it (Marx and Engels 1970/1845, 64).

For us, as for Marx and Engels, the mass media play a crucial role in helping to reproduce ideology and specifically the ideology which maintains capitalism to be an inevitable and immutable 
reality that is here to stay; for it is indeed "the ruling material force of society" (the value-form and profit motive) which "is at the same time its ruling intellectual force". The colossal influence wielded by the media's billionaire owners does indeed filter through all that they own and control, and directly or indirectly through majority and institutional shareholders these same representatives of the capitalist class acquire "the means of material production", thus gaining "control at the same time over the means of mental production". Moreover, in the epoch of reality television in which cameras are turned on atomised (non-)individuals by way of a spurious "democratic" populism, truly "the ideas of those who lack the means of mental production are subject to it", even in those rare instances where they are chosen to be the recipients, fleetingly, of celebrity status. But such subjection is not merely a consequence of neoliberalisation. As Marx and Engels' thesis indicates, the critical problem with the media and cultural industries is not simply that their character is determined by market forces, but that they represent the interests of a ruling class. Any properly Marxist media and cultural studies critique must therefore encompass both the so-called "free market" and the state that underwrites and coordinates that market in the interests of the capitalist class. Indeed, we hold that in the messy field of 'actually existing' social reality, class and class struggle - and not some false and apologetic concept such as 'classism' - exist. Class struggle is, as Walter Benjamin was well aware, the "fight for the crude and material things without which no refined or spiritual things could exist". It is the material struggle between classes - that is, capital against labour and labour's struggle against the capital-labour relation itself, the value relation, and the wage relation - which defines the conditions of emancipation from them, and from abstract labour. To reduce all of this, we would argue, to a struggle against "the market" is to risk abandoning Marxism altogether.

Neoliberalism can be seen, in Andrew Glyn's (2007) phrase, "capitalism unleashed", a "political rationality" (Foucault 1988) entailing the de-socialization of economic activity and the espousal of, inter alia, coercive competition, state rationalization and factor mobility (or "globalization"). Above all, neoliberalism prioritises market forces over state intervention and dirigisme and the emergence of neoliberalism has been marked by a "motivated shift away from public-collective values to private-individualistic ones" (Barnett 2005, 7). The philosophical origins of neoliberalism lie, of course, in the free-market advocacy of economists such as Hayek and Friedman; but it was not until the late 1970s, as a result of a series of so-called "deregulatory" - or better, perhaps, "reregulatory" - policies pursued by Western governments, that neoliberal ideology began to exercise material force. Over the following years, the state has retreated somewhat from social welfare provision and certain areas of economic organisation - through tenders to private third parties bidding for contracts to carry out the functions of the state, most recently observed in the proposal that policing be opened up to this process - resulting in a hyper-financialised, "globalised" economy and an increasingly privatised socio-political order that interpellates individuals as competitive and autonomous, monadic subjects (Harvey 2005). In the same period, media organisations have increasingly tended to defer to market imperatives and the ties that once bound them to the social groups that directed or controlled the state - such as political parties, the unions and the churches, have been loosened, especially in the US (McChesney 2001; Hallin and Mancini 2004; Hallin 2008).

As this broad-brush outline suggests, the concept of neoliberalism helps to illuminate many aspects of Western capitalism's struggle to suppress the working class over the last four decades. As an ideology, neoliberalism sees the market as a supreme good in itself; its accompanying rhetorical emphasis on "freedom" ultimately concerns the freedom to buy and sell and to acquire and maintain property. In effect, the essence of "freedom" becomes economic - the freedom to work or to starve and the freedom to obey laws sanctioning this state of affairs. The neoliberal project might be described as a purer form of capitalism than Keynesianism; in effect: the imposition, as far as possible, of market imperatives at all times and in every area of life - the reign of the "cash nexus", in Marx's famous phrase. In contrast with the post-war Keynesian social compromise of full employment, a strong welfare safety net, public ownership of key industries, and state intervention to "pump prime" the economy when needed, neoliberalism successfully all but destroyed this consensus with its own prescriptions of privatization, deregulation, structural un- 
employment, corporate tax breaks, and welfare "reform". In this sense, the neoliberal project was, and is, also a strategy aimed at restoring and maintaining class power, a response by capital to the seismic shocks generated by the worker and student revolts of the 1960 s and 70 s, no less than the ongoing economic crises of the latter decade (Harvey, 2005).

Nevertheless, some qualifications are in order at this point. The extent to which the scope and remit of the capitalist state has been "rolled back" in recent years, for example, is debatable. John Dewey once remarked that "government is the shadow cast by big business over society" and the nation state remains pivotal in regulating capitalism. As Harvey $(2005,159-164)$ notes, the state has played a pivotal role in the upward redistribution of wealth in recent decades. In fact, without a state to coordinate the system of competition, market competitors would tear one another, and society, to pieces. The nation state thus functions as what Engels, in Anti-Dühring (1947/1878), called the "ideal collective body of all capitalists", regulating the chaos that arises as capitalist interests compete. Left-liberals and the more timid of the "anti-globalization" activists who advocate something similar to the "radical democracy" advocated by Laclau and Mouffe (1986) often complain that the role of the nation state is being usurped by transnational powers such as the International Monetary Fund and the World Bank. Yet these institutions were set up by American imperialism and have operated in its interest ever since. Indeed, given that supra-national bodies such as the OECD, WTO, G8 and G20, not to mention the EU, were all established by liberal democratic states, calling for their reclamation from the market, or from the undue power of neoliberalism, is at best unconvincing. As Ellen Meiksins Wood $(2005,138)$ puts it:

many participants in movements of this kind are not so much anti-capitalist as anti"globalization", or perhaps anti-neoliberal, or even just opposed to particularly malignant corporations. They assume that the detrimental effects of the capitalist system can be eliminated by taming global corporations or by making them more "ethical", "responsible", and "socially conscious".

By the same token, it seems somewhat confused to express the concern that supra-state institutions that were founded by states committed to liberal democracy are "undemocratic" (see for example: Klein 1999; Monbiot 2001; Hertz 2002) for seeking to do the bidding of capital. What such critiques often overlook is the necessary inter-imbrication of the state and the market. Indeed, despite the global nature of the capitalist market, the nation state form remains indispensable for capitalism. As Saskia Sassen (2006) argues, the forces of "globalization", far from abolishing the nation state, operate within it - just as surely as the nation state exists within the global order. Thus, while elements of the nation state have been deterritorialized, the state retains its vital role in capitalist organization. "No other institution", as Wood $(2005,139)$ writes, "has even begun to replace the nation state as an administrative and coercive guarantor of social order, property relations, stability of contractual predictability, or any of the other basic conditions required by capital in its everyday life".

It could even be argued that capitalism's very survival over the last century has been premised upon an increasing fusion of state and market. As early as the end of the nineteenth century, Kautsky observed in The Class Struggle (1971/1892) that the state was being forced to take into its own hands an increasing number of functions, a trend that, as observers such as Bukharin and Trotsky noted, intensified in the early twentieth century. Indeed, at that time, in the face of revolutionary threat and the difficulties posed by the saturation of global markets, the relatively laissezfaire capitalism of the nineteenth century gave way to the statified planning regimes of Stalinism, fascism and New Deal-style social democracy. This interpretation is borne out by economic data from the early twentieth century: in both the UK and US, government spending as a proportion of Gross Domestic Product, while largely static throughout the nineteenth century, began to grow significantly in the 1920s, culminating, of course, in the post-war creation of the welfare state.

Critics of neoliberalism usually suggest that the swelling of the state in the post-war period began to be reversed in the Reagan-Thatcher years. Western capital's tendencies towards privati- 
zation and outsourcing, as well as the erosion of the welfare state since the 1980 s, certainly bear this out. On the other hand, in recent years the US, UK, Irish and Icelandic states have responded to the economic crisis by bailing out failed banks with public money, reminding us that states intervene constantly and crucially in the operations of markets in order to maintain the conditions for capital accumulation. The military expenditures of supposedly neoliberal, Western states, meanwhile, are gargantuan and massive standing armies are used to conquer new markets overseas - an historically unprecedented situation. Such facts problematize any simplistic view of the last few decades as a period during which the state has been in retreat. In fact, from the perspective of the longue duree, the purview of the state can be seen to have significantly increased since the early twentieth century. It seems to us, then, that neoliberalism is a term that must be used with caution; it certainly should not be understood in terms of a simple weakening or diminution of the power of the liberal democratic state. At the very least, the foregoing observations oblige us to recognise neoliberalism as a "hegemonic restructuring ethos, as a dominant pattern of (incomplete and contradictory) regulatory transformation, and not as a fully coherent system or typological state form" (Peck et al 2010, 104; see also Ortner 2011). It might be added that the process of 'neoliberalisation' has not been uniform, affecting some nations and geographical regions more profoundly than others (Hallin and Mancini 2004; Hallin 2008).

This is not to argue that neoliberalism is of no explanatory value to media critics and sociologists. Using the framework of neoliberalism, media sociologists have drawn attention to themes such as the celebritization of politics and the use of low-paid but flexible, or outsourced labour in the media industries (Deuze 2007). At the same time, textual and cultural critics have rightly highlighted some of the profoundly individualising aspects of late capitalist governmentality. In a series of books, Zygmunt Bauman $(2000,2007,2011)$ has convincingly described and condemned the restless, "liquid" lifeworld of late capitalism, while Nick Couldry (2010), David Grazian (2010), John McMurria (2008) and Nick Stevenson (2010) have all commented astutely on the role of reality television in producing flexible, mobile and self-fashioning "entrepreneurial subjects" (du Gay 1996). In a similar vein, Janice Peck (2008) has skilfully outlined the ways in which the individualistic discourses of self-reliance emphasized in the self-help books and television talk shows of Oprah Winfrey serve to reinforce neoliberal orthodoxies. Such work is valuable in illustrating and critiquing the radical de-socialization of the media and cultural industries over the last two decades, prima facie evidence of which can be gleaned from a glance at the lifestyle and consumer programmes that dominate today's television schedules and whose ideal viewer appears to be a self-disciplining homo economicus concerned only with regulating her diet, climbing the property ladder and surgically enhancing her face.

But while the concept of neoliberalism facilitates valuable insights into the ongoing atomisation of contemporary institutions and subjectivities, it is not without its limitations as a tool of critical media analysis. For one thing, while it is true that a good deal of contemporary media culture addresses its audiences as hyper-flexible, autonomous consumers, much of it is also more traditionally propagandistic, aimed at the creation of patriotic citizens of the capitalist state. BBC political discussion programmes such as Question Time, party political broadcasts and, indeed, political journalism in its entirety overwhelmingly reflect the material interests, and reinforce the symbolic power of the capitalist state. So too does the ubiquitous Help for Heroes campaign, which whatever good offices it may facilitate - surely serves to instil nationalist and militarist sentiment. This is to say nothing of the less obtrusive forms of "banal nationalism" (Billig 1995) promoted in nationwide television magazine programmes and sports coverage. Although it may be unfashionable in contemporary media and cultural studies to describe the media in terms of state propaganda, instilling a sense of loyalty to the capitalist nation remains a major function of much of the media we consume, especially in so-called "public service" broadcasting. Such poisonous additives of media propaganda and the contextual fallacy used in the (very) selective presentation of information retards and limits popular understanding of the world, and any critique from emerging - as it is intended to do. Critiques of the media that focus only on "neoliberal" agendas and ideologies risk failing to register this reality. 
Indeed, besides the reactionary media institutions that serve as instruments of right-wing propaganda, there exists in "developed" capitalist societies the far more subtle - and thus far harder to critique - agenda-setting discourse of the liberal media, which sets the terms of what is considered acceptable in public debate, delimits the "sphere of legitimate controversy", in Daniel Hallin's (1986) famous phrase. The public service media, in particular, diffuse and reproduce what is considered acceptable discourse and thereby "manufacture consent" and legitimacy for what will never - and must never - be called into question. In the UK, where both of the authors are based, the news and current affairs programming of BBC and Channel 4 television is sometimes considered more "serious" than that of their commercial competitors. Yet it can be argued that both Channel 4 and the BBC - long the bogus whipping boy of the hysterical tabloid press are in reality at almost every turn faithful servants of vested interests of private wealth and state power (Edwards and Cromwell 2005; Garland 2011; Harper 2012). Historically, for example, the BBC has tended to support the British government's foreign policy during both the Cold War (Jenks 2006) and afterwards (Edwards and Cromwell 2005). Indeed, a Cardiff University study into the BBC's reporting of the Iraq war showed that the BBC was actually less critical of the invasion than its commercial competitors (Lewis 2004). The point here is not that the quantity or quality of "serious" news coverage broadcast by BBC and Channel 4 has diminished in recent years; rather, it is that the "quality" news and current affairs programming on which both channels pride themselves constitutes the "acceptable discourse" of public debate, aimed at legitimizing liberal capitalism and preempting any critique of the system.

Our argument here is that too tight a focus on the undoubtedly malign influence of neoliberalism on politics or culture can cause us to neglect the equally, if not even more problematic machinations of both the state and the liberal media. Here we might consider, as an example, the leftliberal responses to the 2011 phone hacking "scandal" at Rupert Murdoch's News of the World newspaper, in which certain journalists were found to have hacked into the voicemail messages of a range of celebrities and ordinary members of the public. As is well-known, Murdoch's rise to power was facilitated by the "free market" media policies for which he noisily advocated and which he imposed on those who worked for him (McChesney 2001, 14). In fact, Murdoch was an early champion of neoliberal economic ideas and his friendships with politicians who shared what can be seen as his libertarian outlook, such as Margaret Thatcher and Ronald Reagan, were particularly important to his ascendancy (McKnight 2003). Whether explicitly or implicitly, many left-liberal scholars have identified Murdoch's commitment to neoliberalism as a fundamental element in the explanation not only of Murdoch's rise, but also of his fall from grace. One media scholar, for example, notes that the phone hacking scandal took place "in an era of untrammelled neoliberalism" (Savigny 2011). Indeed, identifying neoliberalism as the pernicious ideological background to the scandal, many media academics and activist organisations - such as the liberal campaign group Avaaz - have called for the reform of private media power (Freedman 2011).

Media commentators and victims of the phone hacking have rightly condemned the outrageous malpractice of the News of the World journalists. Yet in lambasting the embodiment of neoliberalism, Rupert Murdoch, in the wake of the scandal, left-liberal critics have tended to overlook the wider political context of the affair. By any standards, Murdoch is a powerful figure in the global media; but it should not be forgotten that Murdoch was brought down by a significantly more powerful coalition of forces, including anti-Murdoch factions within the British state and the nonMurdoch media, such as the BBC and The Guardian. Although the British state had known about phone hacking at the News of the World since at least 2007 (when two of the newspaper's journalists were jailed for related offenses), Murdoch's bid for full control of BSkyB must have raised concerns at the heart of the British establishment. It seems reasonable to suggest that the pro-US stance of the Murdoch media had become increasingly unpalatable to the British state, which may have felt it was time to bring News International under control and, however indirectly, to force Murdoch's hand in closing down his Sunday tabloid. In this context, the humbling of Rupert Murdoch and News International is best understood not as a modest victory for democratic accountability over the forces of global neoliberalism, but as the entrammelling of a globally massive 
but nationally rather inconvenient private power bloc by the formidable forces of a dominant state faction and those elements within the media loyal to it. In class terms, the eruption of the scandal was the result of a well-timed intervention launched by one bourgeois faction against another. To understand Hackgate in this way is not to embrace a conspiracy theory, but to understand that the pragmatic co-operation of the various factions of the capitalist state is forever prone to breaking down, giving way to what Marx, in the third volume of Capital (1967/1894, 253), called a "fight among hostile brothers" whose outcome is "decided by power and craftiness".

Indeed, from a Marxist perspective, the exposure of phone hacking at the News of the World, together with the subsequent official inquiries into media ethics, demonstrates not so much the untrammelled influence of private media corporations, or the malignant effects of neoliberal ideology, as the power of the dominant factions of the nation state to act as an ideologically containing, regulatory force, reigning in or disciplining unruly elements. A class struggle perspective on the phone hacking affair would emphasize that the Leveson Inquiry into the affair and the voices calling for media "reform", far from constituting a counter-hegemonic force, represent a ruling class recuperation: media "reform", through the humbling of News International, was exactly what the dominant faction of the British ruling class sought. In this connection, it might be added that however heinous the crimes of the News of the World phone hackers may have been, it is unlikely that they can compare in their invasiveness to the everyday surveillance activities of the British state - a point politely disregarded in most discussions of the hacking scandal.

None of this is to argue that the current attempts to "reform" the media, via the Leveson Inquiry, are necessarily either regressive or doomed to failure. But our understandable eagerness to condemn the private media power represented by the archetypically "neoliberal" Murdoch empire should not cause us to fall into the trap of uncritically supporting the regulatory reforms now being proposed by a state whose own apparatuses of surveillance may not bear close scrutiny. Nor should it cause us to overlook the thoroughly capitalist nature of the non-Murdoch media. The News of the World may have been the paradigmatic embodiment of confected, salacious scandal and the paper folded with an unconvincing claim that the newspaper's self-declared exceptionalism to the rules governing the "free press" was in defence of those same rules - the better to serve democracy and the best interests of that imaginary demographic, "the public"; but as John Pilger $(2011,21)$ has written:

Britain's system of elite monopoly control of the media rests not on News International alone, but on the Mail and the Guardian and the BBC, perhaps the most influential of all. All share a corporate monoculture that sets the agenda of the 'news', defines acceptable politics by maintaining the fiction of distinctive parties, normalises unpopular wars and guards the limits of "free speech". This will be strengthened by the illusion that a "bad apple" has been "rooted out".

As Pilger's final sentence suggests, the attack on Murdoch by powerful elements of the state and the non-Murdoch media - whatever other effects it may have - has conservative ideological implications, reinforcing the myth that the liberal democratic media are, at least in the normal course of events, unconstrained by powerful interests.

The limitations of neoliberalism as a critical paradigm can also be apprehended through an analysis of the media coverage of the recent, and ongoing, global economic crisis. For many academic critics, the crisis represents a "crisis of neoliberalism" (Beder, 2009; Duménil and Lévy 2011) and of "free market" ideology, meaning "financialization" (Kotz 2008), privatization, deregulation, and an absence of state intervention in the economy. On the other hand, others, most notably the Marxist economist and neoliberalism sceptic Andrew Kliman (2010a, 2010b, 2012), argue that the crisis is rather a crisis of capitalism as a whole, whose fundamental cause is a falling rate of profit (see also Mattick 2011 and Fuchs 2011, 26-29). Kliman also argues (2012, 50-51) that while neoliberalism is useful in describing the dominant political and ideological landscape since the 1980s, "it is not a useful concept for explaining the trajectory of the economy over the 
last several decades". Here is not the place to engage in complicated debates over economic theory. Yet the doubts raised in Kliman's work at least give us leave to question the widespread populist media representation of the crisis as one of unregulated, free market capitalism. For many journalists, the crisis was caused by a short-sighted commitment to "neoliberal ideology", understood in terms of the excesses of a certain form of "extreme" capitalism and widely personified in the tabloid and even the liberal media by the stereotypical (and arguably anti-Semitic) figures of the "greedy banker" and the unscrupulous trader. As the liberal commentator David Marquand $(2010,27)$ put it in an article in The Guardian:

For the last two years we have been living through the third great capitalist crisis of modern times; and it is not over yet. The neoliberal paradigm that has dominated policy-making throughout the developed world, not least in the institutions of global economic governance, has been turned inside out. Markets, we have discovered (or rediscovered), do not always know better than governments. Private greed does not procure public benefits.

It has generally been argued, particularly by left-liberal journalists, that the best remedies for these ills are stronger financial regulation and the fostering of socio-economic "fairness" within the framework of a "responsible capitalism", as the Guardian journalist Polly Toynbee $(2012,27)$ has put it. Liberal journalists have thus tended to understand the economic crisis in populist and moralistic terms, complaining of the rampant greed of the laissez-faire financial sector - a discourse that has been very influential in framing the activities and objectives of the various Occupy movements that have sprung up across the world since 2011. Yet as one Marxist critic, the late Peter Gowan (2009), argues, the problem with such accounts is that

while the New Wall Street System was legitimated by free-market, laissez-faire or neoliberal outlooks, these do not seem to have been operative ideologies for its practitioners, whether in Wall Street or in Washington. Philip Augar's detailed study of the Wall Street investment banks, The Greed Merchants [...] argues that they have actually operated in large part as a conscious cartel - the opposite of a free market.

From this point of view, journalistic explanations of the economic crisis in terms of neoliberalism may have furnished some convenient media scapegoats, but they hardly provide an adequate or accurate account of the causes of, or possible solutions to, the economic recession. The "neoliberalism" theory has become a staple of mainstream media accounts of the crisis; yet the moralism and populism to which it often leads stand in sharp contrast to the materialist analyses of the recession offered by Marxist commentators such as Andrew Kliman (2012) and Paul Mattick (2011).

If neoliberalism is a problematic concept for media and cultural studies critics and practitioners, then so too is its slippery binary opposite, "democracy". In addition to calling for greater regulation of capitalism and capitalist media, critics of neoliberalism typically call for greater democracy in political life. But even where these appeals are not openly nationalist - as they seem to be in appeals to defend "our democracy" (e.g. Fenton 2011) - the tendency to posit democracy as the solution to the ills of neoliberalism is highly problematic for Marxists. For one thing, as Jodi Dean (2010) points out, liberal democracy, far from negating neoliberalism, constitutes its very conditions of possibility. To appeal to the liberal democratic state to reign in neoliberal excesses therefore seems contradictory. Something of the circularity of this position is observable in Michael Moore's documentary film Capitalism: A Love Story (2009). Moore's film movingly depicts the inhuman effects of capitalism upon working class people. However, the ending of the film is more problematic insofar as it seems to lay the blame for the horrors it details at the door of neoliberal, "financialized" and generally "out-of-control" capitalism. The film concludes with shots of Wall Street and Moore's calls for greater regulation of the banking sector; thus, having identified and excoriated many of the injustices of liberal democracy - and clearly insisted upon the need to end 
the capitalist system - Moore proposes that the solution to the financial and institutional corruption he has identified is (and here Moore pauses, as if for thought) "democracy". In fact, Moore has elsewhere argued that his aim in making the film was to encourage his audience to become more "engaged in their democracy" (McGreal 2010, 32). Of course, the cause of the apparent contradiction here lies in Moore's use of two quite different definitions of "democracy": throughout the film, Moore rightly attacks democracy as a form of capitalist governance, while the more positive appeal to democracy at the film's end understands democracy in terms of grassroots, working class decision-making - a definition of democracy consistent with Marxist thought. Moore's argument, then, is not as contradictory as might at first appear. But the potential for slippage in the meaning of "democracy" suggests that, as with "neoliberalism", there is always a danger of backsliding in the direction of liberal and reformist political positions. As Jodi Dean $(2009,94)$ warns:

the appeal to democracy remains unable to elaborate a convincing political alternative because it accepts the premise that we already know what is to be done - critique, discuss, include and revise. Left reliance on democracy thus eschews responsibility for current failures (Look, democracy isn't perfect) but also for envisioning another politics in the future.

For Marxists, indeed, to advocate democracy as the antidote to neoliberalism is not only to mistake the cause for the cure, but also to accept democracy as the goal of class struggle rather than, as Marx put it in "Critique of the Gotha Program" (1970/1875), "the last form of state of bourgeois society".

We would not presume to suggest that the foregoing brief reflections on the theoretical and analytical value of neoliberalism constitute anything like the last word on the matter. Nevertheless, we would argue that there is a need for those media critics and journalists who have recourse to the term "neoliberalism" to consider the ramifications of this usage. Neoliberalism does name verifiable shifts affecting certain areas of Western political and cultural life in recent decades, as noted in the best work on this subject, such as that of David Harvey (2005). Yet the critique of neoliberalism too often functions as what Fredric Jameson (1981) calls a "strategy of containment" that precludes the structural critique of capitalism and its media institutions. Indeed, the political assumptions of many critics of neoliberalism are underpinned by the assumptions of liberalism, according to which a largely benign and neutral state needs to be reclaimed for democracy; anything more radical, after all, smacks of a tyrannising "grand narrative". The solutions suggested by the critics of neoliberalism are usually greater state intervention in the economy and the regulation of capitalism and the capitalist media. Yet, as Richard Wolff (2007) puts it, "leftists who see no further - who criticize neoliberal globalization and advocate a warmed-over welfarestate Keynesianism - have abandoned Marx's critical anti-capitalist project". A Marxist critique must move beyond the critique of "excessive", "financial", "de-regulated" or "neoliberal" capitalism to incorporate a critique of the value-form and the capital-labour relation. It must encompass both the commercial media and their more paternalistic - but no less capitalist - public service counterparts.

Moving beyond the critique of neoliberalism also entails discriminating between intra-class faction fights such as the News of the World scandal and identifying opportunities for working class self-assertion in the media. Indeed, the radical transformation of both the media and society requires the working class to struggle on its own class terrain; "the emancipation of the workers", as the famous phrase has it, "must be the work of the working class itself". To some extent, any radical transformation of the media will require the working class to organize itself and defeat capitalism. On the other hand, while we should be very wary of the often hyperbolic claims made for the liberatory potentials of the Internet and new media (Fuchs 2011; Morozov 2011; Curran et al. 2012), it is clear that new forms of networking and social media - insofar as they remain unbanned by the state and economically accessible to working class people - can promote working class consciousness and organisation against capital (Hands 2010; Fuchs 2011), creating a new 
media, as it were, in the shell of the old. Notably, the only commentary on Hackgate - to the authors' knowledge - that analysed the scandal in relation to its class character and to the tensions within global imperialism has appeared on the website of the Marxist group the International Communist Current (2011). Through this website and thousands like it, ordinary people are able to discuss how to confront and defeat not neoliberalism, but the capitalist system in its entirety.

For Marxists, neoliberalism was never a very adequate critical term, insofar as it has been understood as a regime of accumulation that is parasitical on, or extrinsic to the normal functioning of an otherwise unproblematic capitalism. Embedded in its usage, all too frequently, are the assumptions of liberal democracy, and those who employ the term are often horrified by their belated discovery that the state is, and always has been, hand in glove with capital. In any case, at the levels of policy and economics, the supposedly neoliberal epoch is in many ways over, as sovereign debt crises force capitalist states to adopt increasingly protectionist political strategies. Perhaps now, then, is the time to relinquish neoliberalism as an analytical category. Nor does the term seem to have much rhetorical value for radicals today. Mark Fisher (2009) points to the paradox that capitalism today, in the absence of visible alternatives, is widely understood as the only possible political system, thereby becoming paradoxically invisible. To replace capitalism, as a critical term, with neoliberalism, is to risk complicity with this "making invisible" of capitalism. Bertolt Brecht once quipped that "capitalism is a gentleman who doesn't like to be called by his name"; but if we wish to identify and overcome the socio-political ills of our time, it is imperative, as Jameson $(1991,418)$ recommends in a revival of the famous 1960 s slogan, to "name the system" that causes them.

\section{References}

Barnett, Clive. 2005. The Consolations of "Neoliberalism". Geoforum 36 (1): 7-12.

Bauman, Zygmunt. 2000. Liquid Modernity. London: Polity.

Bauman, Zygmunt. 2007. Liquid Times: Living in an Age of Uncertainty. London: Polity.

Bauman, Zygmunt. 2011. Culture in a Liquid, Modern World. London: Polity.

Beder, Sharon. 2009. Neoliberalism and the Global Financial Crisis. Social Alternatives 8 (1): 17-21.

Benjamin, Walter. 1940/1999. Theses on the Philosophy of History, in Illuminations. London: Pimlico.

Billig, Michael. 1995. Banal Nationalism. London: Sage.

Boltanski, Luc and Ėve Chiapello. 2005 The New Spirit of Capitalism. London: Verso.

Bourdieu, Pierre. 1996. On Television and Journalism. New York: The New Press.

Brown, Wendy. 2006. Neoliberalism, Neo-Conservatism and De-Democratization. Political Theory 34 (6): 690-714.

Couldry, Nick. 2009. My Media Studies. Television and New Media 10 (1): 40-42.

Couldry, Nick. 2010. Why Voice Matters: Culture and Politics after Neoliberalism. London: Sage.

Curran, James, Natalie Fenton and Des Freedman. 2012. Misunderstanding the Internet. London: Routledge.

Dean, Jodi. 2010. Is Democracy Possible? Sure, This is what Democracy Looks Like. Accessed 14 March, 2012. http://jdeanicite.typepad.com/i_cite/2010/12/is-democracy-possible-sure-this-is-what-democracy-looks-like.html

Deuze, Mark. 2007. Media Work. London: Polity.

Du Gay, Paul. 1996. Consumption and Identity at Work. London: Sage.

Duménil, Gérard and Dominique Lévy. 2011. The Crisis of Neoliberalism. Cambridge: Harvard University Press.

Edwards, David,and David Cromwell. 2005. Guardians of Power: The Myth of the Liberal Media. London: Pluto Press.

Engels, Friedrich. 1947/1878. Anti-Dühring. Herr Eugen Dühring's Revolution in Science. Moscow: Progress Publishers.

Fenton, Natalie. 2009. My Media Studies: Getting Political in a Global, Digital Age. Television and New Media 10 (1): $55-$ 57.

Fenton, Natalie. 2011. Murdochgate and the News: We Need to Reframe Media and the Public Interest. Our Kingdom. http://www.opendemocracy.net/ourkingdom/natalie-fenton/murdochgate-and-news-we-need-to-reframe-media-andpublic-interest

Fisher, Mark. 2009. Capitalist Realism. Winchester: Zer0 Books.

Foucault, Michel. 1988. Politics and Reason. In Politics, Philosophy, Culture: Interviews and Other Writings, 1977-84, edited by Lawrence D. Kritzman, 57-85. New York: Routledge.

Freedman, Des. 2011. The BBC is Not Part of the Problem Raised at Hackgate. Accessed 14 March, 2012. http://www.opendemocracy.net/ourkingdom/des-freedman/bbc-is-not-part-of-problem-raised-by-hackgate 
Fuchs, Christian. 2011. Foundations of Critical Media and Information Studies. Abingdon: Routledge.

Garland, Christian. 2011. Simulating Events as They Happen: Media Spectacle, Ideology, and Readymade Bogeymen. http://fu-

berlin.academia.edu/ChristianGarland/Papers/1143145/Simulating_events_as_they_happen_media_spectacle_ideology and_readymade_boogeymen

Glyn, Andrew. 2007. Capitalism Unleashed: Finance, Globalization and Welfare. Oxford: Oxford University Press.

Gowan, Peter. 2009. Crisis in the Heartland. New Left Review 55. Accessed 14 March, 2012. http://www.newleftreview.org/A2759

Grazian, David. 2010 Neoliberalism and the Realities of Reality Television. Contexts 9 (2): 68-71.

Gurevitch, Michael, Tony Bennett, James Curran, Janet Woollacott, eds. 1982. Culture, Society and the Media. London: Methuen.

Hall, Stuart. 1982. The Rediscovery of "Ideology": The Return of the Repressed in Media Studies. In Culture, Society, and the Media, edited by Michael Gurevitch et al., 56-90. London: Methuen.

Hallin, Daniel C. 1986. The Uncensored War: The Media and Vietnam. New York: Oxford University Press.

Hallin, Daniel C. and Paolo Mancini. 2004. Comparing Media Systems: Three Models of Media and Politics. Cambridge, MA: Cambridge University Press.

Hallin, Daniel C. 2008. Neoliberalism, Social Movements and Change in Media Systems in the Late Twentieth Century. In The Media and Social Theory, edited by David Hesmondhalgh and Jason Toynbee, 43-58. Abingdon: Routledge.

Hands, Joss. 2010. @ Is For Activism. London: Pluto.

Harper, Stephen. 2012. Beyond the Left: The Communist Critique of the Media. Winchester: Zer0 Books.

Harvey, David. 2005. A Brief History of Neoliberalism. Oxford: Oxford University Press.

Hertz, Noreena. 2002. The Silent Takeover: Global Capitalism and the Death of Democracy. London: Arrow.

International Communist Current. 2011. http://world.internationalism.org/

Jameson, Fredric. 1991. Postmodernism, or, the Cultural Logic of Late Capitalism. Durham, NC: Duke University Press. Jenks, John. 2006. British Propaganda and the News Media in the Cold War. Edinburgh: Edinburgh University Press. Klein, Naomi 1999. No Logo. Toronto: Knopf Canada.

Kotz, David M. 2008. Neoliberalism and Financialization. http://people.umass.edu/dmkotz/Neolib_and_Fin_08_03.pdf Kliman, Andrew. 2010a. Master of Words: A Reply to Michel Husson on the Character of the Latest Economic Crisis. Marxism 21, 7 (2): 239-281.

Kliman, Andrew. 2010b. A Crisis of Capitalism (Not Neoliberalism, 'Financialised Capialism' or Low Wages). Accessed 14 March 2012. http://www.marxisthumanistinitiative.org/wp-content/uploads/2010/10/a-crisis-of-capitalism-rvsd1027101.pdf

Kliman, Andrew. 2012. The Failure of Capitalist Production: Underlying Causes of the Great Recession. London: Pluto. Kautsky, Karl. 1892/1971. The Class Struggle. New York: W. W. Norton.

Laclau, Ernesto and Chantal Mouffe. 1986. Hegemony and Socialist Strategy: Towards a Radical Democratic Politics. London and New York: Verso.

Lewis, Justin. 2004. Television, Public Opinion and the War in Iraq: The Case of Britain. International Journal of Public Opinion Research 16 (3): 295-310.

Lyotard, Jean-François. 1984. The Postmodern Condition: A Report on Knowledge. Manchester: Manchester University Press.

Marquand, David. 2010. Green, Socialist, Republican: The New Politics Needs a Realignment of Mind: Tarted-up Neoliberalism Won't Cut It. The Great Question of Our Time Isn't the Deficit, but Halting the Capitalist Merry-Go-Round. The Guardian. May 26, 27.

Marx, Karl. 1967/1894. Capital: Volume III. Harmondsworth: Penguin.

Marx, Karl and Friedrich Engels. 1970/1845. The German Ideology. Ed. C J. Arthur. New York: International Publishers.

Marx, Karl. 1970/1875. Critique of the Gotha Programme. Moscow: Progress Publishers.

Mattick, Paul. 2011. Business as Usual: The Economic Crisis and the Failure of Capitalism. London: Reaktion.

McChesney, Robert. 2001. Global Media, Neoliberalism and Imperialism. Monthly Review 52 (10): 1-19.

McGreal, Chris. 2010. "Capitalism is Evil - You Have to Eliminate il": After Guns and the Iraq War, Michael Moore is Now Taking on an Entire Political and Economic System in his Latest Documentary. So What Message Does the Man Who Once Planned to Become a Priest Have? The Guardian, January 30, 32.

McLennan, Gregor. 1989. Marxism, Pluralism and Beyond: Classic Debates and New Departures. London: Polity.

McMurria, John. 2008. Desperate Citizens and Good Samaritans: Neoliberalism and Makeover Reality TV. Television and New Media. 9 (4): 305-332.

McKnight, David. 2003. "A World Hungry for a New Philosophy": Rupert Murdoch and the Rise of Neo-Liberalism. Journalism Studies 4 (3): 347-358. 
Monbiot, George. 2001. Captive State: The Corporate Takeover of Britain. London: Pan Books.

Morozov, Evgeny. 2011. The Net Delusion: How Not To Liberate the World. London: Allen Lane.

Mudge, Stephanie L. 2008. What is Neo-Liberalism? Socio-Economic Review 6 (4): 703-731.

Ortner, Sherry. 2011. On Neoliberalism. Anthropology of This Century 1. Accessed 14 March 2012.

http://aotcpress.com/articles/neoliberalism/

Peck, Janice. 2008. The Age of Oprah: Cultural Icon for the Neoliberal Era. Boulder, CO: Paradigm Publishers.

Peck, Jamie, Nik Theodore, and Neil Brenner. 2010. Postneoliberalism and its Malcontents. Antipode 41: 94-116.

Pilger, John. 2011. Amid the Murdoch Scandal, There's An Acrid Smell of Business As Usual. New Statesman, July 25, 21.

Sassen, Saskia. 2006. Territory, Authority, Rights: From Medieval to Global Assemblages. Princeton NJ: Princeton University Press.

Savigny, Heather. 2011. Media, Murdoch, Morals and Markets: Time for A New Kind of Politics? Accessed 14 March, 2012. http://dmt.uea.ac.uk/media/2011/07/13/media-murdoch-morals-and-markets-time-for-a-new-kind-of-politics/

Stevenson, Nick. 2010. Education, Neoliberalism and Cultural Citizenship: Living in 'X Factor' Britain. European Journal of Cultural Studies 13 (3): 341-358.

Toynbee, Polly. 2012. Miliband Has Been Proven Right: Fairness Does Matter: How You Share Resources in Hard Times Counts More Than How You Share A Growing Cake. Even Cameron Has To Agree. The Guardian, January 10, 27.

Tronti, Mario. 1965. The Strategy of Refusal. Accessed 14 March, 2012. https://webspace.utexas.edu/hcleaver/www/TrontiRefusal.html

Van Dijk, Teun A. 2006. Ideology and Discourse Analysis. Journal of Political Ideologies 11 (2): 115-140.

Wainwright, Hilary. 2003. Reclaim the State: Experiments in Popular Democracy. London: Verso.

Wolff, Richard D. 2007. Neoliberal Globalization is Not the Problem. Monthly Review. Accessed 14 March 2012.

http://mrzine.monthlyreview.org/2007/wolff041207.html

Wood, Ellen Meiksins. 2005. Empire of Capital. London: Verso.

Žižek, Slavoj. 2007. With Defenders Like These, Who Needs Enemies? In The Truth of Zizek, edited by Paul Bowman and Richard Stamp, 197-255. London: Continuum.

\section{About the Authors}

\section{Christian Garland}

Christian Garland is a writer and theorist; he is also a PhD candidate at the University of Warwick and Fellow of the Institut für Kritische Theorie, Freie Universität Berlin. His research interests include the original Frankfurt School and critical media theory. His publications include Refusing the terms of non-existence, breaking their constraints: John Holloway, cracking capitalism and the meaning of revolution today, which is forthcoming in Journal of Classical Sociology (12.2) and, also forthcoming in 2012, Negating that which Negates us: Marcuse, Critical Theory and the New Politics of Refusal in Radical Philosophy Review.

Stephen Harper

Stephen Harper is Senior Lecturer in Media Studies at the University of Portsmouth, UK. His research interests span political and social issues in British television, critical theory and cultural geopolitics. He has written academic articles on a wide range of subjects including British television drama and documentary, dramatic representations of war and media representations of mental distress. He is also the author of Madness, Power and the Media (Palgrave, 2009) and Beyond the Left: The Communist Critique of the Media (Zer0 Books, 2012). 